\title{
Food safety when eating outside: an aspect of tourist safety in Cape Coast tourist destination in Ghana
}

\section{Nicholas IMBEAH}

Enyedi Gyorgy Doctoral School for Regional Sciences, Faculty of Economics \& Social Sciences (GTK), SZIE, H-2100, Gödöllő,, Páter Károly, utca 1, Hungary; E-mail: nicholas.imbeah@tpoly.edu.gh

\section{Keywords: destination, Cape Coast-EImina-Kakum, restaurant, chop bar, inbound tourist}

\section{Introduction}

Tourists' safety increases people's propensity to travel and also empowers tourists to keep their plans and visit destinations they have saved money to travel (Kovari \& Zimanyi, 2011). Destinations should now provide safe food for the tourists in order to be able to stay and enjoy the number of days they intend spending at the destination.

\section{Materials and methods}

This study is a review of sources of eating outlets among the tourists in Cape Coast destination, the tourist hub in Ghana. The sources of various types of food offered for sale at this destination can be grouped under the following: restaurants, "chop bars", drinking spots and home-kitchen food for home visitors or tourists who stay in foster homes/ families.

\section{Results and discussion}

Table 1: Type of tourists, what and where they eat in the public

\begin{tabular}{|c|c|c|}
\hline Type of Tourists & What and where they eat & Observation \\
\hline First time visitors/tourists & $\begin{array}{l}\text { Eat continental or oriental food at the } \\
\text { restaurants and home-kitchen. }\end{array}$ & $\begin{array}{l}\text { They are very conscious about } \\
\text { food security. }\end{array}$ \\
\hline $\begin{array}{l}\text { Repeat visitors/eco- } \\
\text { tourists }\end{array}$ & $\begin{array}{l}\text { Eat local foods at the restaurants, local } \\
\text { chop bars \& home-kitchen. }\end{array}$ & $\begin{array}{l}\text { They have become used to the } \\
\text { foods in the community. They try } \\
\text { other local foods. }\end{array}$ \\
\hline $\begin{array}{l}\text { Tourists/Students on } \\
\text { educational field trip } \\
\text { (mass tourists) \& } \\
\text { conference tourists }\end{array}$ & $\begin{array}{l}\text { Eat continental food and oriental food } \\
\text { at the restaurants } \& \text { food recommended } \\
\text { by the tour operators. }\end{array}$ & $\begin{array}{l}\text { Asian descent tourists patronize } \\
\text { oriental food; European \& } \\
\text { western descent tourists patronize } \\
\text { continental food; some tourists try } \\
\text { local foods. }\end{array}$ \\
\hline $\begin{array}{c}\text { Tourists who stay in foster } \\
\text { homes }\end{array}$ & $\begin{array}{l}\text { Eat more of the home-kitchen food } \\
\text { prepared by their host. }\end{array}$ & $\begin{array}{l}\text { They eat more of the home- } \\
\text { kitchen food and learn how the } \\
\text { food is prepared. }\end{array}$ \\
\hline Tourists of African descent & $\begin{array}{l}\text { Eat all types of food from restaurants, } \\
\text { chop bars \& home-kitchen. }\end{array}$ & $\begin{array}{l}\text { They are daring in eating food of } \\
\text { African origin }\end{array}$ \\
\hline
\end{tabular}

In Table 1 above, the type of tourists, what and where they dine are shown and observations are made about such tourists. In general, tourists are really particular about food they eat in this tourist destination and only few tourists dare to try new foods. Also, there is a plethora of literature about the fact that food law and legislation in Ghana is quite out-of-date and unreliable even at district, municipal, metropolitan, regional, national levels (Ababio and Lovatt, 2015; Monney et al., 2014; Abrokwah, 2013; Nicolò, 2012; Sefa-Dedeh, 2009). There 
are also sets of bye-laws at these levels in Ghana as regards the enforcement of food safety but the effects of enforcement are very weak because of weak institutional logistics. This situation has deepened the weak links among the food safety policy makers, implementors and inspectors such as Ghana Standards Board (GSA), Food and Drugs Authority (FDA), local government authorities (LGAs) and Ghana Tourism Authority (GTA).

\section{Conclusion}

It is recommended that the local sources of food (chop bars) should be regulated and monitored by Ghana Tourist Authority (GTA). This can highly improve the image of the destination in order to increase the tourist arrivals in Ghana. It must be said that food law and regulations should also be updated, institutional responsibilities should be strengthened and coordinated to keep up with food inspection services and food control management in Ghana.

\section{Acknowledgement}

This is a pilot study on food safety as part of tourist safety in Central Region in Ghana. The author would like to thank YAKO Catering Services, Ghana; Department of Tourism, Takoradi Technical University, Ghana and Enyedi Gyorgy Doctoral School for Regional Sciences, SZIE, Hungary, for their support.

\section{References}

Ababio, F. P., Lovatt, P. (2015): A review on food safety and food hygiene studies in Ghana. Food Control, 47, 92-97. DOI: https://doi.org/10.1016/j.foodcont.2014.06.041

Abrokwah, S. (2013): Decongesting the Streets of Accra: The Problems and Prospects (Doctoral dissertation, University of Ghana).

Charles, G. (2014): Regulations and Competitiveness of the Food-Processing Sector in Selected African Countries. In Anderson, W., Chijoriga, M., \& Philemon, J. (2014). Promoting Trade Competitiveness in Developing Countries. 39.

Kovari, I., Zimanyi, K. (2011): Safety \& security in the age of global tourism. Applied Studies in Agribusiness \& Commerce, Vol.5, No.3-4.

Monney, I., Agyei, D., Owusu, W. (2013): Hygienic Practices among Food Vendors in Educational Institutions in Ghana: The Case of Konongo. Foods, 2, 282-294. DOI: https://doi.org/10.3390/foods2030282

Nicolò G. (2012): Report on the Study of street food vending in Ghana 2012. FAO RAF, Accra (Ghana). Unpublished.

Sefa-Dedeh, S. (2009): Ghana: Overview of Food Safety Situation in Africa-Country Position, presentation held at the Presented at the Go-Global Conference. Accra. April. 